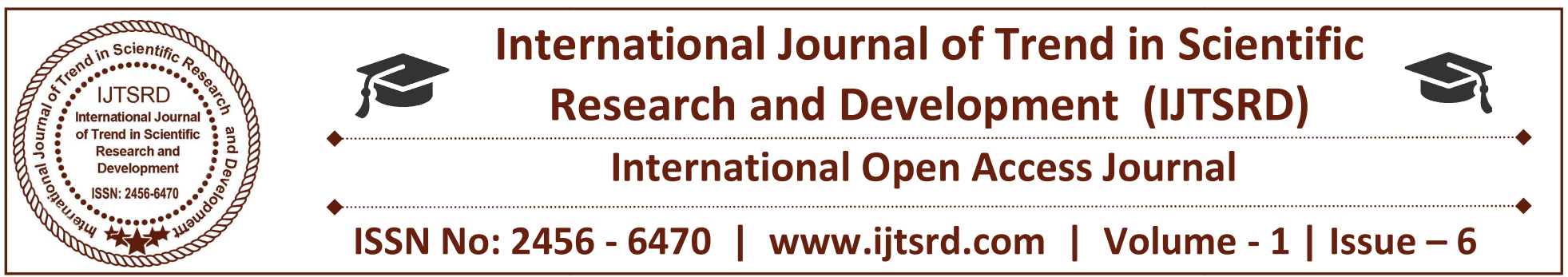

\title{
The GST and Economic Growth
}

\author{
Dr. Arun Kumar Mishra \\ Associate Professor, Shri M.D. Shah Mahila College, \\ Malad West Mumbai-64
}

\begin{abstract}
GST also known as the Goods and Services Tax is defined as the giant indirect tax structure designed to support and enhance the economic growth of a country. To make India as a financial super power, the introduction of GST is must. There are much apprehension relating to proposed GST regime regarding the growth in Indian Economy and its effects thereof. As we know in India economy, destination based taxation requires high compliance cost and efficient administration. This paper examines the impact of goods and services tax (GST) on economic growth India. Only a registered person can charge and collect GST on the taxable supplies of goods and services made by him. GST is charged on the value or selling price of the products. The amount of GST incurred on input (input tax) can be deducted from the amount of GST charged (output tax) by the registered person.
\end{abstract}

\section{INTRODUCTION}

The introduction of Goods and Service Tax (GST) in India is now on the horizon. GST is a consumption based tax levied on sale, manufacture and consumption on goods \& services at a national level. State GST (SGST) which will be levied by State. Integrated GST (IGST) - which will be levied by Central Government on inter-State supply of goods and services. Goods and Services Tax (GST) is an indirect tax which was introduced in India on 1 July 2017 and was applicable throughout India which replaced multiple cascading taxes levied by the central and state governments. . The current indirect tax structure is major impediment in India's economic

growth and competitiveness. Tax barriers in the form of CST, entry tax and restricted input tax credit have fragmented the Indian market. Cascading effects of taxes on cost make indigenous manufacture less attractive. Complex multiple taxes increase cost of compliance. In this scenario, the introduction of GST is considered crucial for economic growth. GST will have quite a favorable impact on Indian economy. Some sectors will have more favorable impact compared to others under the proposed GST. The rollout of the GST has been deferred from its initially intimidated date of April 1, 2017. The delay has been attributed to the hefty issue of dual control, which has clogged the way. The government is now willing to implement the significant taxation reform from July 1, 2017, which is only three months away from the previously speculated timeline.

\section{Importance of GST in Indian Economy:}

GST is one of the biggest indirect tax reforms in the country. GST is expected to bring together state economies and improve overall economic growth of the nation.

GST is a comprehensive indirect tax levy on manufacture, sale and consumption of goods as well as services at the national level. It will replace all indirect taxes levied on goods and services by states and Central. Keeping in mind the federal structure of India, there will be two components of GST - Central GST (CGST) and State GST (SGST). Both Centre and States will simultaneously levy GST across the value chain. Tax will be levied on every supply of 
goods and services. Centre would levy and collect Central Goods and Services Tax (CGST), and States would levy and collect the State Goods and Services Tax (SGST) on all transactions within a State. The input tax credit of CGST would be available for discharging the CGST liability on the output at each stage. Similarly, the credit of SGST paid on inputs would be allowed for paying the SGST on output. No cross utilization of credit would be permitted.

\section{At the Central level, the following taxes are being subsumed:}

1. Central Excise Duty

2. Additional Excise Duty

3. Service Tax

4. Additional Customs Duty commonly known as Countervailing Duty, and

5. Special Additional Duty of Customs.

\section{At the State level, the following taxes are being subsumed:}

1. Subsuming of State Value Added Tax/Sales Tax,

2. Entertainment Tax (other than the tax levied by the local bodies), Central Sales Tax (levied by the Centre and collected by the States)

3. Octroi and Entry tax,

4. Purchase Tax

5. Luxury tax, and

6. Taxes on lottery, betting and gambling.

There are around 160 countries in the world that have GST in place. GST is a destination based taxed where the tax is collected by the State where goods are consumed. India is going to implement the GST from July 1, 2017 and it has adopted the Dual GST model in which both States and Central levies tax on Goods or Services or both.

\section{Positive effects of GST}

GST is a single taxation system that will reduce the number of indirect taxes. Earlier, indirect taxes were charged as central excise, VAT, service tax, etc. From now, a single taxation term would cover all of those indirect taxes.

The Prices of products and services would reduce so this system would prove to be beneficial for the people who are fed up of paying huge prices.
This would reduce the burden from the state and the central government. Presently separate taxes are levied on goods and services that you produce. With the introduction of GST, all of these indirect taxes would come under a single roof.

Market development. GST would not be charged at every point of sale like other indirect taxes so this way, market would be developed.

Corruption-free taxation system. GST would introduce corruption-free taxation system. In the present scenario, the tax is levied at the time of product release from the manufacturing site, and after that retailers also pay it.

Positive impact on the Central and the State level

According to the latest reports, the introduction of GST would help India to gain $\$ 15$ billion every year.

Let us see how:

$>$ Improved exports

$>$ More opportunities for employment

$>$ Enhanced economy growth

$>$ Reduced burden on central and state government.

Experts have enlisted the benefits of GST as under:

$>$ It would introduce two-tiered One-Country-OneTax regime.

It would subsume all indirect taxes at the center and the state level.

$>$ It would not only widen the tax regime by covering goods and services but also make it transparent.

$>$ It would free the manufacturing sector from cascading effect of taxes, thus by improve the cost-competitiveness of goods and services.

$>$ It would bring down the prices of goods and services and thus by, increase consumption.

$>$ It would create business-friendly environment, thus by increase tax-GDP ratio.

$>$ It would enhance the ease of doing business in India.

GST is going to be a critical reform for the Indian economy as it would simplify taxation norms by consolidating a range of taxes under one single umbrella. At present, different states have different tax laws. There are nearly 17 taxes that businesses pay 
to various authorities, making it a cumbersome and expensive affair. GST will result in a simplified tax structure and a unified tax base, with common rules and administrative procedures coming into effect across the country. It will also result in widening of the tax base to include a comprehensive list of goods and services. This will bring in transparency and encourage investments in organized sectors, helping the economy gather growth momentum.

\section{Is GST going to benefit people below the poverty line?}

The effect of GST is actually influenced by the level of income, in which higher income earners will bear lower proportion of their income to pay GST compared with the lower income earners. Thus, this situation arise an important issue as the government intends to implement GST. Such as (1) Can GST stimulate economic growth without burdening the consumption of lower and middle income earners? (2) Does the flat-rate of GST is an efficient way in stimulating revenue and economic growth for developing and developed countries?

With respect to those living below the poverty line, there might not be a direct impact of the GST on them as such since basic necessities like food are unlikely to attract the GST but increased collections of the GST with a larger tax base should provide an impetus to the government to allocate more money for social and poverty alleviation programmes. Thus, the GST should benefit all sections of the society. Additionally, the GST, being a nationwide tax, could lead to possibly higher inflation in the first few years of its introduction but would gradually increase the overall GDP.

\section{Negative impacts of GST}

According to many economists, the introduction of GST in the country would impact real estate market. This would increase new home buying price by $8 \%$ and reduce buyers' market by $12 \%$.

GST levied by the government as CGST for central, SGST for state government are nothing but fantasy terms representing older terms Service Tax, CST, and VAT in a new way.

GST is a confusing term where double tax is charged in the name of a single taxation system.
Most of the indirect taxes would now start coming under GST. The Central excise tax is levied at the time of Manufacturing but GST is levied till the selling stage.

Most of the dealers don't pay central excise tax and cheat the government by simply paying the VAT. But all of those dealers would be forced to pay GST.

This is a clever part of the design of the GST - the Indian government has essentially privatized tax enforcement-but it's another hammer blow to the small businesses that drive India's growth and employment. Meanwhile, the smaller firms that do join up discover that they have to pay their taxes, but don't get their refunds for weeks, perhaps months. This drastically raises their working capital needsagain increasing costs and reducing competitiveness.

\section{Inter-State Transaction}

In case of inter-State transactions, the Centre would levy and collect the Integrated Goods and Services Tax (IGST) on all inter-State supplies of goods and services under Article 269A (1) of the Constitution. The IGST would roughly be equal to CGST plus SGST. The IGST mechanism has been designed to ensure seamless flow of input tax credit from one State to another. The inter-State seller would pay IGST on the sale of his goods to the Central Government after adjusting credit of IGST, CGST and SGST on his purchases (in that order). The exporting State will transfer to the Centre the credit of SGST used in payment of IGST. The importing dealer will claim credit of IGST while discharging his output tax liability (both CGST and SGST) in his own State. The Centre will transfer to the importing State the credit of IGST used in payment of SGST. Since GST is a destination-based tax, all SGST on the final product will ordinarily accrue to the consuming State.

\section{Conclusion}

Implementation of GST is one of the best decision taken by the Indian government. For the same reason, July 1 was celebrated as Financial Independence day in India when all the Members of Parliament attended the function in Parliament House. The transition to the GST regime which is accepted by 159 countries would not be easy. Confusions and complexities were expected and will happen. India, at some point, had to 
comply with such regime. Though the structure might not be a perfect one but once in place, such a tax structure will make India a better economy favorable for foreign investments. Until now India was a union of 29 small tax economies and 7 union territories with different levies unique to each state. It is a much accepted and appreciated regime because it does away with multiple tax rates by Centre and States

\section{References}

1) Aasness, Jorgen, Andreas Benedictow and Mohamed F. Hussain (2002), "Distributional Efficiency of Direct and Indirect Taxes", Rapport 69, Economic Research Programme on Taxation.

2) Acharya, Shankar, "Thirty Years of Tax Reform in India", Economic and Political Weekly, Vol. 40, No. 20, May 2005, pp. 2061-2069.

3) Bishnoi, Usha, Union Taxes in India, Chugh Publications, Allahabad, 1980.

4) Central Statistical Organisation (2008): "InputOutput Transactions Table 2003-04”, GOI, Ministry of Statistics \& Programme Implementation, Central Statistical Organisation, New Delhi.
5) Central Statistical Organisation (2008): "InputOutput Transactions Table 2003-04”, GOI, Ministry of Statistics \& Programme Implementation, Central Statistical Organisation, New Delhi.

6) Desai, Mihir A. and James R. Hines (2002): "Value-Added Taxes and International Trade: The Evidence".

7) Duggal, Monica, Corporate Tax Planning, Published Ph. D. Thesis, RBSA Publishers, Jaipur, 2006.

8) Gandhi, V.P., Some Aspects of India's Tax Structure- An Economic Analysis, Vora \& Co. Publishers, Bombay, 1970.

9) Goenka, B.B., Corporate Tax Planning- A Study of Selected Indian Companies, Unpublished Thesis submitted to Delhi University, 1983.

10) Islam, Azizul (2001), "Issues in Tax Reforms", published in Asia-Pacific Development Journal, Volume 8, Number 1.

11) Jain, A.K., Direct Taxation in India: Some Aspects, RBSA Publishers, Jaipur, 2001. 